\title{
ДОКУМЕНТАЛЬНЫЕ ПУБЛИКАЦИИ
}

\author{
А. Ю. Дворниченко, М. С. Белоусов
}

\section{ДВИЖЕНИЕ ДЕКАБРИСТОВ В ТВОРЧЕСТВЕ ГЕОРГИЯ ВЕРНАДСКОГО}

Статья посвящена анализу темы истории декабризма в творчестве Г.В.Вернадского. Исследование масонства Екатерининской эпохи привело ученого к истории тайных лож начала XIX столетия, а они, в свою очередь, как начальная страница истории декабризма, привлекли внимание к тайным обществам. К сожалению, переломные годы Гражданской войны и последующих мытарств и переездов не позволили Г.В. Вернадскому завершить работу над этой темой монографическим исследованием. Но по сохранившимся материалам мы видим, что его наблюдения стали органичным продолжением дореволюционной историографической традиции, в рамках которой историк формировался. Он высказал много ценных мыслей, расширяющих представления об истории движения декабристов. Предложил собственное начертание эволюции политического мышления деятелей тайного общества и проанализировал особенности идейной борьбы в рамках декабристских организаций, обращался к важной проблеме влияния правительственного конституционализма на формирование программных документов декабристов. После эмиграции научные интересы историка смещаются в сторону древнерусской истории. Тем не менее в работах разных лет он обращается и к декабристским сюжетам. Он затрагивает их в близких по тематике статьях: исследует взаимоотношения декабристов и А.С.Пушкина, рассматривает проблему влияния идей Великой французской революции и их распространения в России. В послевоенный период Г. В. Вернадский выступает с публичной лекцией, текст которой публикуется в приложении к предлагаемой статье ${ }^{1}$. Этот текст можно датировать 1947 г. Перед нами размышления сформировавшегося 60-летнего ученого. Историк стремится определить место декабристов в российской истории. Он показывает, насколько значительной и переломной эпохой для развития страны была первая четверть

Дворниченко Андрей Юрьевич - доктор исторических наук, профессор, Санкт-Петербургский государственный университет, Российская Федерация, 199034, Санкт-Петербург, Университетская наб., 7-9; a.dvornichenko@spbu.ru

Белоусов Михаил Сергеевич - кандидат исторических наук, доцент, Санкт-Петербургский государственный университет, Российская Федерация, 199034, Санкт-Петербург, Университетская наб., 7-9; m.belousov@spbu.ru

Dvornichenko Andrey Yurievich - Doctor of History, Professor, St. Petersburg State University, 7-9, Universitetskaya nab., St. Petersburg, 199034, Russian Federation; a.dvornichenko@spbu.ru

Belousov Mikhail Sergeevich - PhD of History, Associate Professor, St. Petersburg State University, 7-9, Universitetskaya nab., St. Petersburg, 199034, Russian Federation; m.belousov@spbu.ru

1 Авторы статьи сердечно благодарят куратора Бахметевского архива Колумбийского университета Татьяну Чеботарёву за разрешение опубликовать текст выступления Г. В. Вернадского.

(c) Санкт-Петербургский государственный университет, 2017 
XIX столетия, а в заключение лекции предлагает слушателям представить, каким путем пошла бы история, если бы декабристы победили. Библиогр. 23 назв.

Ключевые слова: декабристы, восстание 14 декабря 1825 г., Г. В. Вернадский.

Для цитирования: Дворниченко А. Ю., Белоусов М.С. Движение декабристов в творчестве Георгия Вернадского // Вестник Санкт-Петербургского университета. История. 2017. Т. 62. Вып. 2. С. 358-374. DOI: 10.21638/11701/spbu02.2017.212

\section{A. Yu.Dvornichenko, M. S. Belousov}

\section{DECEMBRIST MOVEMENT IN THE CREATIVITY OF GEORGE VERNADSKY}

The article is devoted to the analysis of the theme of the history of Decembrism in the works of G. V.Vernadsky. The study of freemasonry in the Catherine's epoch led Vernadsky to the history of secret lodges of the beginning of the $19^{\text {th }}$ century, and they, in turn, being the initial page of the history of Decembrism, attracted his attention to the study of secret societies. Unfortunately, the pivotal years of the civil war and the ordeals of relocation did not permit G.V.Vernadsky to complete the work on this topic by monographic research. But according to the surviving materials, we see that his observations became an organic continuation of the pre-revolutionary historiographic tradition within which he was formed. He proposed his own outline of the evolution of the political thinking of the figures of the secret society and analyzed the features of the ideological struggle within the framework of the Decembrist organizations. He appealed to the important problem of the influence of governmental constitutionalism on the formation of the program documents of the Decembrists. After emigration, the historian's scientific interests shift toward ancient Russian history. Nevertheless, in works of different years he addresses to the Decembrist subjects. In the postwar period, he makes a public lecture, the text of which is published as an annex to the proposed article. This text can be dated to the year 1947 . The historian aspires to assess the place of the Decembrists in Russian history. It shows how significant and crucial the epoch for the development of the country was the first quarter of the $19^{\text {th }}$ century. And in conclusion he offers his listener to imagine: how would history have gone if the Decembrists had won? Refs 23.

Keywords: Decembrists, Decembrist uprising, G. V. Vernadsky.

For citation: Dvornichenko A.Yu., Belousov M.S. Decembrist movement in the creativity of George Vernadsky. Vestnik of Saint Petersburg University. History, 2017, vol. 62, issue 2, pp. 358-374. DOI: $10.21638 / 11701 /$ spbu02.2017.212

Выдающийся русско-американский историк Георгий Владимирович Вернадский известен прежде всего как один из отцов-основателей евразийства и знаток русской истории с древнейших времен до XVII в. включительно. Именно этому периоду он посвятил свою знаменитую «Историю России» - последний труд такого плана в мировой историографии. Но Г.В.Вернадский не был бы именно выдающимся историком, если бы не пытался осмыслить последующие эпохи российской истории, найти и в них скрытый смысл и основной вектор развития страны. Мешали неумолимое время и жизненные обстоятельства: многое не удалось, не получило должного воплощения в статьях, книгах и докладах. Но, оставив без внимания эту сферу его творчества, не изучив темы, которые его влекли, мы обедним историографию, да и научный образ историка-подвижника. Среди такого рода тем отнюдь не на последнем месте стоит движение декабристов.

В 1910 г. Георгий Владимирович окончил историко-филологический факультет Московского университета, защитив под руководством видного историка М. М. Богословского кандидатское сочинение на тему «Общественная программа дворянских наказов в Екатерининскую комиссию 1767 г.» $^{2}$. Вскоре его интересы,

\footnotetext{
2 Текст данного сочинения не сохранился.
} 
как это бывает у многих молодых ученых, изменились, сместившись в сторону изучения неизведанной тогда «страны» Сибири. Но затем свои властные изменения внесла и сама жизнь: его знаменитый отец после печально известной коллизии 1911 г. в Московском университете перебрался в Петербург, где в Петербургском университете продолжилась научная жизнь младшего Вернадского.

В имперской столице вновь возродился интерес к российскому «осьмнадцатому» веку, а встреча с первым учителем (еще по гимназии) Я. Л.Барсковым, учеником В.О.Ключевского, оформила этот интерес более конкретно: молодой ученый занялся историей масонов. Выбор оказался во многом удачным. С одной стороны, масонство XVIII в. было (и, наверное, продолжает оставаться) малоизученной и плохо осознанной страницей нашей истории, с другой стороны, этот выбор открывал перед историком широкие перспективы. Молодой исследователь подчеркивал: «...Меня заинтересовали широкие международные связи русского масонства и возможность исследования его на фоне истории европейской умственной жизни» [Вернадский 1995, с. 136]. Самая первая фраза введения первого издания книги «Русское масонство в царствование Екатерины IІ» (апрель 1917 г.) раскрывает широту и панорамность этой темы: «Предлагаемая книга - очерки не из истории религии или философии, а из истории духовной культуры общества» [Вернадский 2001, с. 5].

Магистерская диссертация Вернадского стала важной вехой в изучении масонства. Историк внимательно и скрупулезно анализирует собранные по крупицам источники и предлагает подробную картину эволюции масонских организаций. Вывод, сформулированный в заключении, с одной стороны, резюмирует содержание исследования, с другой - указывает дальнейшее направление творчества историка: «...масонство несомненно способствовало созданию того типа [людей], который надолго получил значение в русском дворянском обществе» [Вернадский 2001, с. 318].

В «петербургский период» творчества историка, помимо книги о масонах, появляются ценные статьи, посвященные Манифесту о вольности дворянской и «законодательной комиссии 1754-1766 гг.», Уложенной комиссии 1767-1768 гг., брошюра о Н. И. Новикове [Вернадский 1918b]. Уже в первой комиссии историк обнаружил зародыш дворянской конституции [Вернадский 1915, с. 54, 59] и проследил преломление этой идеи в последующих событиях [Вернадский 1918а]. Г. В. Вернадский видит в масонах отнюдь не секту, а форму существования политической оппозиции в недрах самодержавной монархии. Эти наблюдения в совокупности с идеями о возможности появления дворянской конституции становятся своеобразным базисом для исследования тайного общества декабристов, которые сами состояли в масонских ложах.

В Государственном архиве Российской Федерации, в фонде, объединяющем доэмигрантские документы о жизни и творчестве историка, сохранились подготовительные материалы для исследования истории масонства первой четверти XIX в. [Выписки из дел...]. Здесь находятся и две статьи уже непосредственно по декабристской тематике, впоследствии опубликованные в 1990-е годы. Первая из них посвящена анализу конституционных проектов П.И.Пестеля и Н.М.Муравьева. Это небольшое незаконченное эссе получило название «Пределы государственного вмешательства и права граждан» [Пределы государственного вмешательства...], опубликованное под странным наименованием «Предел и беспредел» [Вернадский 
1993а]. Сразу же отметим, что про «беспредел» в очерке нет ни слова. Центральный сюжет - насколько государство может вмешиваться в жизнь граждан и ограничивать их права согласно П. И. Пестелю и Н. М. Муравьеву. По тексту этой небольшой статье разбросана целая вереница интереснейших мыслей и наблюдений.

Г. В. Вернадский обращает внимание на ключевое отличие двух законотворцев: для Н.М.Муравьева главное - свобода граждан, и источник его политического мышления - американская конституционная мысль; П.И. Пестель во главу угла ставит общественное благоденствие и ради этой цели допускает серьезное вмешательство государства в частную жизнь граждан. Можно утверждать, что в этой работе Г. В. Вернадский стремится изучить нюансы и особенности конституционного мышления декабристов, тем самым продолжая дореволюционную историографическую традицию [Семевский 1909]. Стоит обратить внимание, что близкие по духу рассуждения можно обнаружить в неопубликованной работе А.Н. Шебунина, современника Г. В. Вернадского [Шебунин]. К сожалению, в отечественной историографии эта тенденция вскоре прервалась. М.В. Нечкина провозглашает восстание декабристов первой неудачной попыткой буржуазно-демократической революции, соответственно и в проектах декабристов «первостепенными по значению оказываются те стороны проектов, которые в совокупности своей ведут к подрыву феодальной формации» [Нечкина 1955, с. 426].

Не ускользнула от внимания историка и другая интересная деталь. Авторы проектов предполагали разные формы их использования. Для П.И. Пестеля «Русская Правда» - это перечень мероприятий, которое тайное общество должно реализовать после прихода к власти. Поэтому историк подчеркивает, что «Русская Правда» должна была храниться в секрете [Вернадский 1993, с. 59]. Н. М. Муравьев предполагал, закончив «Конституцию», широко ее распространять, использовать для пропаганды своих идей, на что обратил внимание Г. В. Вернадский. Но в дальнейшем оба проекта стали восприниматься исключительно как памятники конституционного мышления без учета планируемой декабристами формы их использования.

К доэмигрантскому периоду творчества относится также статья «Два лика декабристов» [Вернадский 1993b], законченная в 1919 г. В этой работе историк предлагает полноценную концепцию истории тайных обществ. Во введении он стремится определить место декабристов в истории России и называет их родоначальниками революционного движения [Вернадский 1993b, с.83]. Размышления историка еще раз подтверждают, что знаменитая в недавнем прошлом ленинская периодизация истории общественного движения была впитана вождем мирового пролетариата из самой интеллектуальной атмосферы революционной эпохи [Цамутали, Белоусов 2015, с.9-10]. Эта же атмосфера позволила по-новому взглянуть на декабристов: новые идеи, факты, чувства перемешались в одном котле. Г. В.Вернадский подчеркивает наибольшее отличие декабристов от позднейших революционеров: «психология декабристов была психологией офицеров победоносной армии, после победы чувствующих свое право и обязанность на участие во власти и поддержку этой власти» [Вернадский 1993b, с. 83].

Мысль историка стремится за грань общеизвестных истин, представлений об общеизвестных организациях. Он замечает: «...Тайные общества росли как грибы - казалось, что они вносят хоть что-то устойчивое в расшатавшиеся умы» [Вер- 
надский 1993b, с.83]. Своим стремлением видеть не историю тайного общества, а эпоху тайных обществ Вернадский во многом предвосхитил развитие историографии. Обратим внимание, что именно эта мысль, сформулированная в 1919 г., является краеугольным камнем одного из наиболее авторитетных современных исследований [Бокова 2003]. Далее историк пишет: «Тайные общества возникли первоначально вовсе не как союз либеральной оппозиции или революционный заговор. Это была позднейшая, уже вторичная форма. Первоначально была налицо не столько либеральная оппозиция, сколько консервативная; имел место не революционный заговор, а соединение желающих поддержать и укрепить власть против всяческой внутренней неурядицы» [Вернадский 1993b, с. 84]. Таким образом, в качестве основной причины возникновения тайных обществ Вернадский выдвигает стремление участников стать опорой для власти в деле реформирования Российской империи. Историк видит в этом органичное продолжение деятельности масонских организаций предшествующей эпохи: «Чрезвычайно важны и поучительны первоначальные связи тайных обществ с масонскими ложами» [Вернадский 1993b, с. 84]. Первые политические тайные общества в России возникли по примеру масонских лож. Следовательно, и в предположительном способе действий этих обществ надо искать масонское влияние.

Здесь следует отметить, что еще А.Н.Пыпин высказывал идею о том, что деятельность декабристских организаций является, по сути, продолжением политических исканий начала Александровской эпохи [Пыпин 1885]. Г. В. Вернадский эту мысль развивает и показывает конкретные пути и формы эволюции масонских организаций и их политического мышления. Естественным продолжением масонства, согласно мнению историка, стало стремление создать более масштабную политическую организацию по примеру прусского Союза Добродетели. К сожалению, развитие этой историографической тенденции было прервано. М. В. Нечкина среди причин возникновения тайного общества указывает и на роль заграничных походов, и на отрицательное отношение к крепостному праву [Нечкина 1955, с. 81140], но в ее концепции декабристские организации появляются на «пустом месте», масонство расценивается не более чем форма конспирации.

Таким образом, Г.В.Вернадский связывает консервативно-патриотическую идеологию масонства с политическим мышлением лидеров и основателей первых декабристских организаций - М. А. Дмитриева-Мамонова, М. Ф. Орлова, А. Н. Муравьева, М. Н. Муравьева. Согласно наблюдениям историка, с первых дней истории декабристских тайных обществ им противостоял П.И.Пестель. Он стремился организовать Союз Спасения по типу заговорщицких итальянских вент [Вернадский 1993b, с. 85]. Как подчеркивает историк, «Пестель был идеологом новых либерально-демократических доктрин, радикалом и якобинцем» [Вернадский 1993b, с. 86]. Борьба этих двух начал, двух течений (консервативно-патриотического и якобинского) и составляла главный нерв политической борьбы внутри декабристских организаций.

В 1821 г. началось наблюдение за тайными обществами. Именно это подтолкнуло «консервативных» лидеров к закрытию Союза Благоденствия. По мнению историка, созданное Пестелем Южное общество стало полноценной революционной организацией, а «Северное общество представляло попытку найти средний путь между Пестелем и двумя Михаилами (Муравьевым и Орловым)» [Вернадский 
1993b, c. 87]. Но их постепенный отход от дел привел к возвышению К.Ф.Рылеева и началу перестройки Северного общества в «заговорщическую организацию пестелевского склада» [Вернадский 1993b, с.87]. Если продолжить ход рассуждений Вернадского, необычайно любопытной представится совместная деятельность К. Ф.Рылеева и С.П. Трубецкого над подготовкой петербургского восстания.

Но, рассматривая этот эпизод, Г. В. Вернадский фокусирует внимание на другом аспекте проблемы - религиозности декабристов. Пытаясь разобраться в психологии участников мятежа, он подчеркивает: «При всех порывах ненависти к тиранам, при всех словесных обещаниях уничтожить императорскую фамилию вряд ли хоть один из членов этих обществ мог бы действительно исполнить эти обещания» [Вернадский 1993b, с.87]. Верность присяге, религиозность, моральный излом - вот что помешало заговорщикам 14 декабря исполнить свои планы. Здесь историк выступает предтечей разворачивающихся у нас сейчас исследований в рамках истории ментальностей, повседневности и пр. Не случайно автора работы подобного профиля привлекла блестящая характеристика декабристов, данная историком [Орлова 2008, с. 524].

Но стоит отметить, что о «моральной прострации» в эти годы писал не только Г. В. Вернадский. Похожую конструкцию использовал Н. Ф. Лавров, характеризуя поведение С.П. Трубецкого на допросах [Лавров 1926, с. 217]. Едва ли можно предположить, что исследователь, ранее не занимавшийся историей тайных обществ и вынужденный писать юбилейную статью про лидера декабристов, был знаком с неопубликованной работой Г.В.Вернадского. Видимо, перед нами еще одна из идей, витавших в воздухе.

Именно рассуждения о душевном надломе многих членов тайного общества заставляют историка вернуться к поставленной в начале статьи проблеме - психологии декабристов. Анализ их религиозности, поведения в решающий момент восстания и на следствии подталкивает к выводу, что по своему психологическому складу они не были революционерами. Вместе с тем среди деятелей тайного общества оформилось новое течение, которое ушло далеко вперед по пути рационализма. Отсюда финальный вывод: «На декабристах два знамени, у них два лика. Один рационалистический, интернационально-революционный, карбонарский. Другой - религиозный, патриотический, бытовой» [Вернадский 1993, с. 91].

Получается внешне весьма противоречивая картина. В начале статьи говорится о родоначальниках революционного движения, о людях с новой психологией, отличающихся по мироощущению от прежних заговорщиков и бунтовщиков, в заключительной части - о людях, которым мировосприятие не позволило нажать на курок пистолета, направленного на Николая Павловича. Представляется, что в наблюдениях историка нет противоречий: само по себе тайное общество было крайне противоречивым, в нем шла сложная политическая эволюция, происходила борьба течений и мнений. Это и удалось увидеть Г. В. Вернадскому. Но пройдет несколько десятков лет, и под пером историков «советской генерации» декабристы станут монолитной политической партией, организованной по принципу демократического централизма. Тонкий и скрупулезный анализ, проведенный историком, станет добычей архивной пыли.

В том же бурном 1919 г. Г. В. Вернадский, находясь в Крыму, делает доклад, впоследствии опубликованный в качестве статьи, - «Скрытый источник конституции 
Никиты Муравьева. Конституция Никиты Муравьева и Государственная уставная грамота Новосильцева» [Вернадский 1919]. В этой работе исследуется крайне важный для понимания конституционализма декабристов сюжет. Историк убедительно показывает, что через П. А. Вяземского Н.М. Муравьев был знаком с проектом Н.Н.Новосильцева, но сознательно умолчал об этом на следствии. Знакомство Н. М. Муравьева с правительственным проектом Конституции оказало на него значительное влияние. Как и у Н.Н. Новосильцева, в тексте муравьевской «Конституции» представлена идея федеративного устройства России.

Остается только сожалеть, что мысль, высказанная историком, не получила дальнейшего продолжения, хотя и была воспринята историографией 1920-1930х годов. Наблюдения историка использует исследователь биографии П.А. Вяземского С.Н.Дурилин [Кутанов 1932]. Но в дальнейшем сама постановка вопроса о влиянии правительственного конституционализма на декабристские проекты становится невозможной.

В 1920 г. Г. В. Вернадский покидает Россию. Начинается новый этап его биографии и научного творчества. Подводя итог анализу доэмигрантских произведений по декабристской тематике, мы видим, что интерес к этому сюжету был органичным продолжением работы над магистерской диссертацией, а та, в свою очередь, стала развитием студенческих штудий. Исследование масонства Екатерининской эпохи привело ученого к истории тайных лож начала XIX столетия, а они, в свою очередь, как начальная страница истории декабризма, привлекли внимание к изучению тайных обществ. К сожалению, события Гражданской войны и эмигрантские скитания не позволили Г.В.Вернадскому завершить работу над этой темой монографическим исследованием. Но по сохранившимся материалам можно убедиться, что его наблюдения стали органичным продолжением дореволюционной историографической традиции, в рамках которой он сформировался. Историк высказал много ценных мыслей, расширяющих представления об истории движения декабристов. Сегодня эти мысли в целом поддержаны современной историографией. Но тогда, в 1930-е годы, они оказались незаслуженно забыты. Началось формирование сталинской концепции истории, и декабристы должны были стать первенцами свободы.

После отъезда из России сфера научных интересов ученого смещается в сторону древности. Тем не менее он продолжит обращаться к декабристской тематике. В 1937 г. он участвует в сборнике, посвященном столетию со дня смерти А.С. Пушкина, со статьей по декабристской тематике [Vernadsky 1937]. Центральная канва статьи: взаимоотношения великого русского поэта и деятелей тайных обществ. Статья состоит из нескольких разделов. В первом рассматривается генезис декабристских организаций. Здесь историк предлагает уже сформировавшийся и отразившийся в предшествующих исследованиях взгляд: либеральные искания Александра I явились важнейшим фактором развития масонских организаций в политическое тайное общество, а внутри общества были представлены самые разные идейно-политические течения. Эволюция декабризма, согласно наблюдениям историка, представляла собой сложный, подчас противоречивый процесс. В последующих разделах анализируются взаимоотношения А.С.Пушкина и деятелей декабристских организаций. Г.В.Вернадский стремится с максимальной широтой охватить возможные контакты и взаимосвязи поэта и декабристов, рассматривая 
его участие в литературных организациях (Арзамас и Зеленая Лампа), личное знакомство с П.И. Пестелем, пребывание на юге в начальный период греческой революции, общение с семьей Раевских. Уделяется внимание поступкам А. С. Пушкина в период междуцарствия и следствия над декабристами. Историк резюмирует свои наблюдения выводом: проблема восстания против сильной власти является важнейшим сюжетом его творчества.

Обращение к теме истории движения декабристов присутствует и в неопубликованной статье, которая датируется самим историком примерно 1947 г. Он изучает тему влияния всех французских революций на Россию. Впрочем, «влияние», с его точки зрения, - сомнительное понятие. В процессе взаимного общения разных народов и наций мы видим механическое заимствование иностранных идей и образа жизни только потому, что они кажутся модными, а не потому, что они реально чтото значат для тех, кто их перенимает. В других случаях идеи перенимают, поскольку они позволяют прогрессивным элементам лучше сформулировать и быстрее развивать свой собственный критицизм по отношению к старому порядку в их стране. Идеи могут заимствоваться частично или по-другому интерпретироваться. Наконец, в новой форме они могут возвращаться в страну своего происхождения и, видоизменившись, звучать как иностранные [The French Revolution and Russia, p. 1-2].

История заимствования идей из Франции, по мнению историка, подтверждает такую схему. Во второй половине XVIII в. французские идеи были модными в России, но усилий по их адаптации не предпринималось. Но уже в правление Александра I французское влияние четко различимо в реформах и проектах реформ. Российский император не только не ограничивал эксперименты с новыми идеями у себя дома, но готов был применять их и за рубежом. В своей «Инструкции» Н.Н.Новосильцеву, отправлявшемуся на переговоры в Лондон в 1804 г., он выступил с планом европейской федерации. Кстати, на Западе историки отдавали должное этим российским попыткам организовать Европейский Союз [Mirkin-Guetzévitch 1933, p. 677-694] в отличие от отечественных ученых, которых данный сюжет ни в какой мере не привлек.

В другой статье, появившейся в печати в 1947 г., историк очень убедительно показывает влияние французской «модели» на российскую «реформационную лихорадку» времен «петербургского Сфинкса». Сделать это исследователю не так уж трудно, поскольку цивилизация российская начиная с предыдущего столетия была буквально пронизана элементами цивилизации французской [Vernadsky 1947, p.47-55]. Сложнее было, конечно, с Соединенными Штатами. Впрочем, контакты существовали, и довольно интенсивные, в том числе в связи с Аляской. По мнению историка, американская Конституция была главной моделью для Государственной уставной грамоты наряду с польской Конституцией 1815 г. [Vernadsky 1947, p. 59]. Но для нас важнее другое: из этих влияний историк во многом выводил и первые ростки революционного движения в России. При этом исследователя поражает близость проектов декабристов к реформаторским планам правительства. Мысль П. И. Пестеля идет тем же путем, что и у М. М. Сперанского, но у него железная воля и есть настоящий революционный темперамент, потому его программа чисто якобинская. «Конституция» же Н. М. Муравьева весьма напоминает Государственную уставную грамоту Н. Н. Новосильцева [Vernadsky 1947, p. 61-63]. 
В докладе, прочитанном в том же 1947 г., историк говорил, что декабристы не только представляют политический либерализм в России, но их движение связано с общим прогрессом в России и интенсивной ферментацией идей. Их появление приходится на период быстрого прогресса во всех сферах, прежде всего в поэзии, архитектуре, науке. Это время ранних стадий индустриализации. Значит, политическое движение декабристов - только один аспект общего прогресса в стране. Надо также принять во внимание важнейшие военные и политические события данного периода. Это было время Наполеоновских войн, в которых декабристы принимали активное участие [The Decembrists, p. 1-2].

Автор отмечает также еще одну существеннейшую особенность движения это не только часть русской истории, но и один из аспектов международного политического и интеллектуального движения и ключевая часть развития западной цивилизации и западных политических идей этого периода. Очень важно, что декабристы были озабочены сменой не только политических, но и социальных форм организации - демократизацией России и решением крестьянской проблемы. Ведь именно крестьянская проблема тормозила реформаторскую деятельность правительства. Историк считает существенным моментом решимость в области крестьянского вопроса, которую демонстрировали декабристы, хотя на этот предмет у них были разные взгляды.

Рассказав об основных декабристских организациях, Г.В.Вернадский обращает внимание на то, что и Южное общество, и Общество соединенных славян были в тесной связи с польскими организациями. Историк охарактеризовал и различия в их конституционных проектах, показав, что проект П.И.Пестеля был более радикальным, в частности, в подходах к формам будущей государственности. Если Н.М.Муравьев (под влиянием американской Конституции) выступал за федерацию, то П.И.Пестель был сторонником централизованной республики. Здесь возникает интересная параллель с правительственными проектами реформ: проект М.М.Сперанского предполагал централизованное правление, а Грамота Н.Н.Новосильцева предлагала федерацию. Это можно объяснить тем, что и те и другие имели одни и те же источники информации. Без сомнения, и Н. М. Муравьев, и Н.Н. Новосильцев были хорошо знакомы с Конституцией США, так же как П.И.Пестель и М.М.Сперанский - с французским конституционализмом [Тhе Decembrists, p. 7].

Что касается П.И.Пестеля, то он был не только за объединенную Россию, но и за сверхцентрализованное правительство - верил в большие государства, а из наций делал исключение только для поляков. Симпатии к полякам были сильны среди многих декабристов. Для изучения эволюции идей П. И. Пестеля интересен его трактат, который, по-видимому, был написан в 1815 г. или 1816 г. В этом раннем трактате он выступает за освобождение крестьян, но без земли. Его подход вполне сходен с подходом Н.М. Муравьева и других членов Северного общества. Затем он изменил свою точку зрения, и в «Русской Правде» представлен оригинальный план наделения населения землей без подавления индивидуальной инициативы в агрикультуре.

Охарактеризовав более подробно позицию по этому вопросу П.И. Пестеля, историк закончил доклад совершенно неожиданным образом: предложил слушателям на минуту представить, будто восстание декабристов победило! Не только 
история России, но и история Европы могли бы изменить свой курс, а может быть, и история всего мира. Свободная Россия и свободная Польша, союз между ними это возможность понимания между Восточной Европой и Францией. Историк набросал еще несколько штрихов и только тогда закончил лекцию [The Decembrists, p.10-11]. В риторическом приеме, использованном в этом выступлении, можно увидеть всю квинтэссенцию изучения Г. В. Вернадским истории декабризма.

Г. В. Вернадский как историк сформировался в дореволюционной России: получил образование, написал и защитил магистерскую диссертацию. Но затем бури революций и Гражданской войны заставили его оказаться сначала в белом Крыму, потом в Праге и наконец в США.Г.В. Вернадский - по образованию российский историк, по обстоятельствам научной карьеры - американский. Базисом его исторических взглядов является дореволюционная историография, и характерные для нее идеи и подходы отражаются и развиваются в работах историка. Творчество Г. В.Вернадского демонстрирует тот путь, по которому могла бы пойти дореволюционная историография, если бы не Смута начала XX в. Парадоксально, но в работах Г.В.Вернадского мы находим мысли и наблюдения, которые современным историкам пришлось «открывать заново».

ПРИЛОЖЕНИЕ

\author{
G. Vernadsky
}

\title{
The DeCEMbrists
}

The Decembrists represented not only political liberalism In Russia, but their movement was connected with general progress in Russia and with the very extensive fermentation of ideas. We speak of the Decembrists as revolutionists, but as a matter of fact, it is not only in its political aspects that Russia experienced a period of considerable change and rapid progress, but in other spheres of life as well. It was the period of the blossoming of Russian poetry, with Pushkin to represent it. It was a period of interesting development in Russian architecture. I can mention the names of such architects as Zakharov, Voro... There was considerable progress in science. Vassily Petrov, a physicist of genius, just at this period experimented with electricity and electric light. It was also the period of the early stages of industrialization in Russia. The Treaty of Tilsit in 1807 and Anglo Russian alliance and the Continental blockade gave considerable impetus to the development of Russian industry. The number of both factories and factory workers more than doubled in the period between 1800 and 1825. So when we think of Decembrists and discuss the Decembrists, we have to think of their political movement as only one aspect of the general progress in Russia in this period, which may more or less be characterised by the German formula of Sturm und Drang, and this is, of course, a very important point. Also, we have to take into consideration the important military and political events of the period. 
It was the age of the Napoleonic wars, and most of the Decembrists took active part in that heroic military effort of Russia, and took part in the campaign of Russian troops abroad, their march to Paris.

In addition to those various aspects of the Decembrist movement and the general progress in Russia during this period, we may also say that the Decembrist movement and the development of political ideas in Russia in general at this time was not exclusively a part of Russian history. It was, of course, basically and essentially a Russian movement, but because of the intellectual and spiritual connection of both the liberal leaders and statesmen of Russia of that period with the West, we may also say that this was one of the aspects of the international political and intellectual movement of this period, and although it is not sufficiently realized, I think it was an important part of the development of Western civilization and Western political ideas in this period.

The Decembrists themselves were also influenced by the political events in Europe in this period. I mentioned the fact that most of them participated in the Russian campaign to Paris, that meeting between the East and the West - a similar meeting took place in Berlin during the last war, but in 1814, the meeting was Paris, so that the Russians and had even farther to go to meet the West. The meeting has certainly brought important result. As a matter of fact, when we

speak of Russia and the fleet we always think of the West as more of progressive. Just at that moment in the matter [of] political situation there was not much progress in the West. The victory of the Allies over Napoleon meant the end of Napoleon's imperialism, but it also meant the restoratuion of the Bourbons and the suppression of the more liberal movements for the time being. Even the limited constitutional charter which France was granted was more or less the result of the policy of Alexander the I of Russia. Just at that moment, in 1814, France could not be much of an example for any revolutionary development in Russia, and yet the result of this meeting between Russia and the West was a very important one. As our Chairman showed it in his interesting article on the Decembrists published in the Monde Slave in 1925, the future Decembrists, when they got to Paris, were shocked by the political reaction there, but at the same time many of them, including Pavel Pestel perhaps the most important of the Decembrists - were impressed by the fact that even though France had gone back, still the social achievements of the revolution remained in France. As Pestel said it in his statement to the court in 1826, this was a fact which impressed him very ranch, and when thinking of the possibility of a revolution, he came to the conclusion that even if the revolutionary government would not last long in Russia, still important social changes would be achieved. It is essential to emphasize just this aspect in the ideas of the Decembrists - that they were interested not only in the change of

political forms - the form of government - but that one or their basic ideas was the necessity of a social change - democratization of Russia, and so the peasant problem occupied a very important part in all of their projects, which is perfectly clear from their 
memoirs and their statements during the trial. I said in my preceding lecture that the most difficult point in bringing about reform in Russia was the necessity of solving simultaneously the political problem and the social problem, of dealing with both autocracy and difficulty of handling the problem of serfdom was one of the causes of the slow progress in the government's projects of reform. It is to the credit of the Decembrists that they understood well the significance of this important point, and so in spite of the difference in their opinions about details of the future Russian constitution, they formally agreed and formally resolved to abolish serfdom in Russia and to start the activity of the future would be revolutionary government just by dealing with the problem of serfdom. This was a very important point not only from the angle of the development of the political ideas, but also of the practical problem of action.

As you know, the Decembrist movement was a failure - a failure for various reasons; there were major and minor causes for the failure. One of the important contributing causes of the failure of the Decembrists was the fact that the leading man among them was arrested on the eve of the revolt. But even though the movement was failure, the fact that the Decembrists paid so much attention to the peasants was

significant for the future - following the Decembrist movement, the social problem became an indispensable item in all phases of the progressive movement in Russia. The fact that the Decembrists emphasized this point shows that they were well acquainted with the Russian realities and that they actually could have received support from the Russian people had their revolution had any chance of actually being started. While we may say that the important leaders of the movement were in agreement about the emancipation of the peasants, there were many differences of opinion among them about other problems of the future, such as the political organization of Russia, also the manner in which the emancipation of the peasants could be realized.

As you know, the first political secret societies of the Decembrists period started immediately after the Napoleonic wars. There were several satges in the organization of these groups, but finally it became plain that there were in existence in Russia three major revolutionary groups - the so called Northern Society, which centered around St. Petersbourg, among the members of which was Nikita Muraviev, the author of one of the important constitutional projects. The poet Ryleyev was also a member of the Northern Society. Then there was the so-called Southern Society, more or less centering around Kiev. The leader of this group was Pestel. The third important group was the socalled Society of the United Slavs. We have no detailed program of this last organisation - only a few glimpses of information about their program. The most interesting aspect of this program was Panslavism.

This movement, which we may call partly Russian and partly Ukrainian, was also connected with Polish Slavophil ideas. Both the Southern Society and the Society of United Slavs were in close connection with the Polish Revolutionary societies. The result was 
this panslavic movement of the United Slavs, who spoke of the future federation of all the Slavs, and who used to speak of the Black Sea and the Adriatic Sea as Slavic Seas.

We are much better acquainted with the programs of the Southern and Northern Societies because the two versions of the constitution project of N. Muraviev have been kept. We also have the unfinished copy of Pavel Pestel's important work known as Russkaya Pravda or Russian Law. The word Pravda means Truth and also Justice. Undoubtedly Pestel thought of that old Russian word and in my opinion we have to translate Russkaya Pravda as Russia Law. There were many important divergences between Muraviev's project and Pestel's project. On the whole we say that Pestel's project was much more radical politically, because Pestel advocated a republic, while Muraviev was ready to accept a constitutional monarchy. Pestel's project was also much more radical socially. While Muraviev was ready to emancipate the peasants, in his opinion - end in the opinion of the majority of the members of the Northern Society - the land in each estate was not to be given to the peasants. The landowners were to retain the estate, the peasants were to receive their personal freedom and their homesteads, but the bulk of the estate was to be kept by the former landlord. Pestel on the

\section{[7]}

contrary was for giving the peasants sufficient amounts of land. Pestel's ideas of agrarian reform were extremely interesting and original. But let us first deal with some other general aspects of these two constitutional projects. Another difference between the Muraviev and the Pestel project was that Muraviev was in favor of federation; his constitutional project was considerably influenced by the constitution of the U.S. Pestel was for a centralized republic, and this was a very important point. We have here a very interesting parallel to the difference in the Governmental project of reform, which I mention in my preceding talk. Speransky's project of 1789 favored centralized government, while Novosiltzev's 1820 Constitutional Charter of the Russian Empire recommended federation. We may explain this coincidence in the government's projects and the Decembrists' project partly by the fact that both the Government leaders and the Decembrists had more or less the same source of information. Undoubtedly both Muraviev and Novosiltzev were well acquainted with the constitution of the U.S. On the other hand Pestel and Speransky were well acquainted with the French constitutional reforms and the constitutional development in France. In addition to this general background, in my opinion it is quite possible that Muraviev, when he was writing his project, was aware of the existence of Novosiltzev project. Novosiltzev's project was not published at that time, but one of Novosiltzev's assistants was Prince Viazemsky, a friend of Pushkin and of many Decembrists, so it is quite possible that there was some relationship between Munviev and Novosiltzev.

As for Pestel, he was not only for a United Russia, but for a very centralist government in Russia. He believed in big states, and was not in favor or small nations. He argued that there is a conflict between two principles in this respect, what he called the Right of Nationality and the Principle of State Convenience, or if you like, Strategic Security. These two principles, according to Pestel, are at constant variance, and in each case it is to be 
decided which principle is to be given consideration. Pestel argues that states such as Finland or small national groups such as the Tartars in Russia, while thy the elements of nationality, are too insignificant and too small by themselves, so their existence would only result in a conflict between the two neighboring empires or large states. Pestel came to the conclusion that Poland and the Poles were the only group of real significance in Russia, and he advocated the independence of Poland and its separation from Russia, however on some conditions. The first condition was to be that Poland accept the same democratic constitution as Russia would have. The second condition was that Poland would conclude a permanent treaty of friendship with Russia. On those two conditions he was ready to grunt independence to Poland. In this respect there is not much difference between Pestel and some of other Decembrists. Pestel and some of the other Decembrists. Pestel, as well as the members of the United Slavs, was pro-Polish. There was much pro-Polish feeling among the members of the Northern Society also, On the other hand

the Northern Society of Muraviev provided for the automony of small groups, which were to form a federation of state.

With regard to the peasant problem, we are now in a position to follow pretty closely the development of Pestel's ideas, because while Russkaya Pravda - Pestel's main work was disovered and published even before the Russian Revolution, another work of Pestel - a minor one - has appeared. This minor work is very interesting for the study of the development of his ideas. It gives a clear understanding of Pestel's early ideas on the agrarian problem. There is difference of opinion among scholars on the date of that treatise of Pestel's on political economy, also on the question as to whom he was influenced by in writing this treatise. The editor of Pestel's treatise suggests (1925) that Pestel was under the influence of a noted economist of this period

that Pestel was under the influence of a noted economist of this period Sismondi, and since Sismondi's main work appeared in 1818, it was suggested that Pestel's work must have been written in 1819. Several years later there appeared an article by G in Russkiya Zapiski in Prague, who remarked that Sismondi's influence was not noticeable. Pestel himself mentions Sismondi, but only in collection with paper money, so it seems that Pestel wrote this treatise on political economy in 1815 or 1816 . At that early stage Pestel's program did not differ from the program of Muraviev and the other members of the Northern Society. He was in favor of emancipating the serfs, but not of giving them land. Later he changed his opinion, and in the Russkaya Pravda we have a very original plan supplying the while population of Russia

[10]

with land and same time not suppressing individual in agriculture. What Pestel suggested was a division of all of the land into fund each of the peasants, each of the members of the township was to have a share. In the other category, the principle of private property was recognized, but again the government had to take measures so that as many people as possible could use this land, even on a private basic. So here we have not only a complete difference between Pestel and the members of the Northern Society, but we also find an 
entirely new point of view and new ideas on the agrarian question. This point in Pestel's program is one of the most significant features ofhis program.

I have no time to go into more details on those projects, but I would like to say a few words in general about the general about the significance of the Decembrist movement and about the possibilities inherent in this movement. Let us for a moment imagine that the Decembrists were victorious. Not only the history of Russia, but the history of Europe would have clanged its course, we may even say the history of the world. We would then have a combination of a free Russia and a free Poland and a union between Russia and Poland, and so the possibility of an understanding between Eastern Europe and France. The Bourbon revolution in France could have come much earlier, and if we think of the era of Jacksonian democracy in the States, we have a vision of a democratic world established long ago. If we think of Pestel's agrarian plan, we may think of the social developments in Russia.

\section{$[11]$}

Just now some of the ideas of the Decembrists have come true. The members of the United Slavs spoke of the Black and the Adriatic Seas as Slavic Seas - there are some such trends at present. When Pestel was ready to grant independence to Poland, his condition was the establishment of a democratic government in Poland. The present situation seems not so far from Pestel's recommendation. These, of course, are merely details, but I think there is agreement in many respects.

\section{Источники и литература}

Бокова В. М. Эпоха тайных обществ. Русские общественные объединения первой трети XIX века. М.: Реалии-Пресс, 2003. 651 с.

Вернадский Г. Два лика декабристов // Свободная мысль. 1993. № 15. С. 81-92.

Вернадскии Г. В. Из воспоминаний // Вопросы истории. 1995. № 1. С. 129-148.

Вернадский Г. В. Императрица Екатерина II и Законодательная комиссия 1767-1768 гг. // Сб. общества истории, философии и социальных наук при Пермском университете. Вып. 1. Пермь: 2-я Государственная типография, 1918а. С. 43-65.

Вернадский Г. В. Манифест Петра III о вольности дворянской и законодательная комиссия 17541766 гг. // Историческое обозрение: сб. статей Исторического общества при Императорском С.-Петербургском ун-те / изд. под ред. Н.И.Кареева. Т.20. Пг.: Типогр. М. М.Стасюлевича, 1915. С. 51-59.

Вернадский Г. В. Николай Иванович Новиков. Пг.: Наука и школа, 1918b. 163 с.

Вернадский Г. В. Скрытый источник конституции Никиты Муравьева. Конституция Никиты Муравьева и Государственная уставная грамота Новосильцева // Известия Таврического университета (Симферополь), 1919. № 1. С. 127-147.

Вернадский Г. В. Русское масонство в царствование Екатерины II. СПб.: Издательство Н. И. Новикова, 2001. 575 c.

Выписки из дел Государственного архива к работе Вернадского Г. В. по истории масонства времен декабристов // Государственный архив Российской Федерации (ГАРФ). Ф.1137. Оп. 1. Д.91.

Кутанов Н. (Дурилин С.Н.) Декабрист без декабря // Декабристы и их время. Труды московской и ленинградской секций по изучению декабристов. М.: Изд-во Всесоюзного общества политкаторжан и ссыльно-поселенцев, 1932. С. 201-290.

Лавров Н. Ф. Диктатор 14 декабря // Бунт декабристов. Л.: Былое, 1926. С. 129-222.

Нечкина М. В. Движение декабристов. Т. І. М.: Изд-во Академии наук СССР, 1955. 481 с.

Орлова Т. В. Движение декабристов с точки зрения ментальностей // Декабристы. Актуальные проблемы и новые подходы. М.: РГГУ, 2008. С. 520-531. 
[Вернадский Г.В.] Пределы государственного вмешательства и права граждан // Государственный архив Российской Федерации (ГАРФ). Ф.1137. Оп.1. Д. 60.

Пьпин А. Н. Общественное движение в России при Александре І.СПб.: Типогр. М. М. Стасюлевича, 1885. 543 c.

Семевский В.И. Политические и общественные идеи декабристов. СПб.: Типогр. Первой СанктПетербургской Трудовой Артели, 1909. 694 с.

Шебунин А.Н.Декабристы // Отдел рукописей Российской национальной библиотеки (ОР РНБ). Ф. 849. Оп. 1. Д. 73.

Цамутали А.Н., Белоусов М. С. 190-летие восстания декабристов // Вестн. С.-Петерб. ун-та. Сер. 2. История. 2015. Вып. 4. С. 5-19.

Mirkin-Guetzévitch B. Un projet de fédération européenne en 1804 // Mélanges Nicolas Iorga. Paris: Librairie université J. Gamber, 1933. P.677-694.

[Vernadsky G. ] The Decembrists // The Burler Bakhmeteff Archives (BAR). GVP. Box. 96. Arranged Manuscripts. Notes of G. Vernadsky. G. V.11 p.

[Vernadsky G.] The French Revolution and Russia // The Burler Bakhmeteff Archives (BAR). GVP. Box. 114. Arranged Manuscripts. Notes of G. Vernadsky. G. V.20 p.

Vernadsky G. V. Pushkin and the Decembrists // Centennial essays for Pushkin. Cambridge: Harvard University Press, 1937. P. 45-76.

Vernandsky G. Reforms under Czar Alexander I // The Review of Politics. 1947. January. Vol. 9, no. 1. P. 47-64.

\section{Reference}

Bokova V.M.Epokha tainykh obshchestv. Russkie obshchestvennye ob"edineniia pervoi treti XIX veka [Period of secret public associations of the first third of the XIX century]. Moscow, Realii-Press Publ., 2002, 651 p. (In Russian)

Vernadsky G. Dva lika dekabristov [Two Faces of the Decembrists]. Svobodnaia mysl' [Free thought], 1993, no. 15. pp. 81-92. (In Russian)

Vernadsky G. V. Iz vospominanii [From the memories]. Voprosy istorii [Questions of history], 1995, no. 1, pp. 129-148. (In Russian)

Vernadsky G. V.Imperatritsa Ekaterina II i Zakonodatel'naia komissiia 1767-1768 [Empress Catherine II and the Legislative Commission of 1767-1768]. Sbornik obshchestva istorii, filosofii i sotsial'nykh nauk pri Permskom universitete [Collection of the Society for History, Philosophy and Social Sciences at Perm University]. Vol. 1. Perm', 2-aya Gosudarstvennaya tipografiya [ $2^{\text {nd }}$ State Printing House], 1918a, pp. 43-65. (In Russian)

Vernadsky G. V.Nikolai Ivanovich Novikov. Petrograd, Nauka i shkola Publ., 1918b, 163 p. (In Russian)

Vernadskiy G. V. Manifest Petra III o vol'nosti dvorianskoi i zakonodatel'noi komissii 1754-1766 gg. [Manifest of Peter III on the liberties of the nobility and the legislative commission of 1754-1766]. IIstoricheskoe obozrenie: sb. statei Istoricheskogo obshchestva pri Imperatorskom S.-Peterburgskom un-te [Historical Review. Collection Articles of the Historical Society under the Imperial St. Petersburg University]. Vol. 20. Petrograd, M. M. Stasyulevich Print. House, 1915, pp. 51-59. (In Russian)

Vernadskiy G. V.Russkoe masonstvo $\mathrm{v}$ tsarstvovanie Ekateriny II [Russian Freemasonry in the reign of Catherine II]. St. Petersburg, N. I. Novikov Publ. House, 2001. 575 p. (In Russian)

Vernadsky G. V. Skrytyi istochnik konstitutsii Nikity Murav'eva. Konstitutsiia Nikity Murav'eva i Gosudarstvennaia ustavnaia gramota Novosil'tseva [The hidden source of the constitution Nikita Muraviev. Constitution Nikita Muraviev and State Charters of Novoseltseva]. Izvestiia Tavricheskogo universiteta [Proceedings of the Tauride University] (Simferopol), 1919, no. 1, pp. 127-147. (In Russian)

Vypiski iz del Gosudarstvennogo arkhiva k rabote Vernadskogo G. V. po istorii masonstva vremen dekabristov [Excerpts from the affairs of the State Archives in the work of Vernadsky G. V. on the history of Freemasonry times Decembrists]. Gosudarstvennyi arkhiv Rossiiskoi Federatsii [State Archives of the Russian Federation] (GARF), f. 1137, op. 1, d. 91. (In Russian, unpablished)

Kutanov N. (Durilin S. N.) Dekabrist bez dekabria [Decembrist without December]. Dekabristy i ikh vremia. Trudy moskovskoi i leningradskoi sektsii po izucheniiu dekabristov [Decembrists and their time. Proceedings of the Moscow and Leningrad sections on the study of the Decembrists]. Moscow, The All-Union Society of Political Prisoners and Exiles-Settlers Publ., 1932, pp. 201-290. (In Russian)

Lavrov N. F. Diktator 14 dekabria [Diktator on December 14]. Bunt dekabristov [The revolt of the Decembrists]. Leningrad, Byloe Publ., 1926, pp. 129-222. (In Russian) 
Nechkina M. V.Dvizhenie dekabristov [Movement of the Decembrists]. Vol. I. Moscow, Publ. by The Academy of Sciences of the USSR, 1955, 481 p. (In Russian)

Orlova T.V.Dvizhenie dekabristov s tochki zreniia mental'nostei [The movement of the Decembrists in terms of mentalities]. Dekabristy, Aktual'nye problemy i novye podkhody [Decembrists, Actual problems and new approaches]. Moscow, Russian State University for Humanities (RGGU) Publ., 2008, pp. 520-531. (In Russian).

[Vernadsky G.] Predely gosudarstvennogo vmeshatel'stva i prava grazhdan [Limits of State Intervention and Citizens' Rights]. Gosudarstvennyi arkhiv Rossiiskoi Federatsii [State Archives of the Russian Federation] (GARF), f. 1137, op.1, d. 60. (In Russian, unpablished).

Pypin A. N. Obshchestvennoe dvizhenie v Rossii pri Aleksandre I [Social movement in Russia at Alexander I]. St. Petersburg, M. M. Stasiulevich Print. House, 1885, 543 p. (In Russian)

Semevskiy V. I. Politicheskie i obshchestvennye idei dekabristov [Political and social ideas of the Decembrists]. St. Petersburg, Print. House of the First St. Petersburg Labor Artel, 1909, 694 p. (In Russian)

Shebunin A. N. Dekabristy [Decembrists]. Otdel rukopisei Rossiiskoi natsional'noi biblioteki [Department of Manuscripts of the Russian National Library] (OR RNB), f. 849, op. 1, d 73. (In Russian, unpablished).

Tsamutali A.N., Belousov M.S. 190-letie vosstaniia dekabristov [The $190^{\text {th }}$ anniversary of the Decembrist uprising]. Vestnik of Saint-Petersburg University. Series 2. History. 2015, issue 4, pp. 5-19. (In Russian)

Mirkin-Guetzévitch B. Un projet de fédération européenne en 1804 [A project for a European federation in 1804]. Mélanges Nicolas Iorga [Mixes Nicolas Iorga]. Paris, Publ. by The Librairie J. Gamber University Library, 1933, pp. 677-694. (In French)

[Vernadsky G.] The Decembrists. The Burler Bakhmeteff Archives (BAR). GVP, Box. 96. Arranged Manuscripts, Notes of G. Vernadsky G. V., 11 p. (Unpablished)

[Vernadsky G.] The French Revolution and Russia. The Burler Bakhmeteff Archives (BAR). GVP, Box. 114. Arranged Manuscripts. Notes of G. Vernadsky G. V., 20 p. (Unpablished).

Vernadsky G. V. Pushkin and the Decembrists. Centennial essays for Pushkin. Cambridge, Harvard University Press, 1937, pp. 45-76.

Vernandsky G. Reforms under Czar Alexander I. The Review of Politics, 1947, January, vol. 9, no. 1, pp. 47-64.

Received: 26.12 .2016

Accepted: 22.05.2017 